\title{
Bioremediation of Tannery Wastewater by Chromium Resistant Fungal Isolate Fusarium chlamydosporium SPFS2-g
}

\author{
SMILEY SHARMA ${ }^{1}$ and PIYUSH MALAVIYA ${ }^{1,2 *}$ \\ ${ }^{1}$ Department of Environmental Sciences, University of Jammu, Jammu (J\&K) India. \\ ${ }^{2}$ Laboratory of Environmental Pollution Analysis, Faculty of Biology, \\ University of Warsaw, Warsaw. Poland.
}

http://dx.doi.org/10.12944/CWE.9.3.21

(Received: November 14, 2014; Accepted: December 12, 2014)

\begin{abstract}
The present study assessed the bioremediation potential of Fusarium chlamydosporium SPFS2-g isolated from tannery effluent enriched soil. The isolate exhibited minimum inhibitory concentration (MIC) for $\mathrm{Cr}(\mathrm{VI})$ as $500 \mathrm{ppm}$. The treatment of tannery wastewater with Fusarium chlamydosporium in shake flask experiment resulted in the reduction of chemical oxygen demand (COD), color, $\mathrm{Cr}(\mathrm{VI})$, total suspended solids (TSS), turbidity, $\mathrm{Na}^{+}, \mathrm{Cl}^{-}$, and $\mathrm{NO}_{3}^{-}$in the order of $71.80,64.69,100,36.47,22.77,11.69,27.87$ and $62.33 \%$, respectively after six days of treatment duration.
\end{abstract}

Key words: Bioremediation, Chromium, Fungi, Wastewater.

\section{INTRODUCTION}

Tanning industry is considered to be a major source of pollution and tannery wastewater in particular, is a potential environmental concern'. The wastewater emanating from tanneries is characterized by a strong color and is heavily polluted with high COD and biochemical oxygen demand (BOD) and inorganic impurities (sodium, calcium, nitrate, ammonia, sulfide, and chloride), dissolved and suspended solids, and other specific pollutants such as vegetable and/or synthetic tannins, sulfonated oils, chromium, Pentachlorophenol and surfactants ${ }^{2,3}$. These colored wastewaters hamper light penetration ${ }^{4}$, whereas high COD results in decreased dissolved oxygen in the aquatic ecosystem ${ }^{5}$. Similarly, chromium toxicity is also one of the major causes of environmental hazards caused by tannery effluents. Chromium exists in several oxidation states (I-VI), more stable as $\mathrm{Cr}(\mathrm{III})$ and $\mathrm{Cr}(\mathrm{VI}) . \mathrm{Cr}(\mathrm{VI})$ is the toxic form of the element ${ }^{6}$ which causes severe diarrhoea, ulcers, eye and skin irritation, kidney dysfunction and probably lung carcinoma ${ }^{7}$. Conventional methods for removing toxic $\mathrm{Cr}(\mathrm{VI})$ include chemical reduction followed by the precipitation under alkaline conditions, ion exchange, and adsorption on activated coal, alum, kaolinite, and $a^{2}{ }^{8}$. Most of these methods have major disadvantages; for instance, a need for high energy use and large quantities of chemical reagents, incomplete metal removal and generation of large quantity of toxic waste sludge ${ }^{9}$. Furthermore, such processes may be ineffective or extremely expensive when the initial heavy metal concentrations are in the range of $10-100 \mathrm{mg} \mathrm{L}^{-1}$ as well as high organic load in the effluent ${ }^{10}$.

Microorganisms (bacteria/fungi) are the most important eco-friendly agents for the degradation and detoxification of industrial pollutants during the biological treatment of industrial wastewaters. Therefore, bioremediation is an alternative to conventional chemical and physical methods for wastewater treatment ${ }^{11}$. Fungi are 
known to tolerate heavy metals ${ }^{12}$. They are a versatile group, as they can adapt and grow under various extreme conditions of $\mathrm{pH}$, temperature and nutrient availability, as well as high metal concentrations ${ }^{13}$. They offer the advantage of having cell wall material which shows excellent metal-binding properties ${ }^{14}$. Generally, microbial biomasses have evolved various measures to respond to heavy metals stress via processes such as transport across the cell membrane, biosorption to cell walls, entrapment in extracellular capsules, as well as precipitation and transformation of metals ${ }^{15}$. There are some studies which have been conducted employing bacteria for remediation of components of tannery wastewater ${ }^{16}$, ${ }^{17}$ or fungal mycelia as bioabsorbent ${ }^{18,19}$. But, most of the studies are pollutant specific targeting only one or two specific pollutants mostly chromium. We could not find even a single study on remediation of COD, color and major ions of tannery wastewater. Therefore, the aim of the present study was to isolate and select fungal strain from tannery effluent enriched soil which can be able to remove the COD, color, $\mathrm{Cr}(\mathrm{VI})$ and other major ions from the leather industry wastewater.

\section{MATERIALS AND METHODS}

\section{Sample collection}

The tannery wastewater used in the bioremediation studies was collected in polyethylene containers from the final discharge section of a tannery located in Central Leather Research Institute (CLRI) complex, Kapurthala Road, Jalandhar, India. On the other hand, for soil enrichment study, the tannery wastewater was collected from the chrome tanning stage. The collected samples were brought to the laboratory and stored in a refrigerator at $4{ }^{\circ} \mathrm{C}$ till their utilization.

\section{Isolation and identification of potential fungal strain}

For artificial soil enrichment experiments, an area of 1 square feet in a garden was selected where tannery effluent with gradually increasing concentrations was added for eighteen months. For the isolation of fungal strain the soil was serially diluted, centrifuged at $900 \mathrm{rpm}$ for five minutes and the supernatant was used for further enrichment in modified Lee's minimal medium without glucose $\left(0.25 \% \mathrm{KH}_{2} \mathrm{PO}_{4}, 0.20 \% \mathrm{MgSO}_{4}, 0.50 \%\left(\mathrm{NH}_{4}\right)_{2} \mathrm{SO}_{4}\right.$ and $0.50 \% \mathrm{NaCl}$ ) containing tannery sludge as sole source of carbon in Erlenmeyer flasks for three days (150 rpm, $28^{\circ} \mathrm{C}$ ). This process was repeated several times with fresh sludge amended minimal salt medium (MSM). The final set of flasks were used for subsequent plating and isolation of fungi on sludge containing MSM plates. The $\mathrm{pH}$ of the medium was maintained at 5.30 with 100 $\mathrm{mM} \mathrm{L}^{-1}$ citrate-phosphate buffer ${ }^{20}$. The inoculated petriplates were incubated at $28 \stackrel{\circ}{\circ}$ for seven days. The fungal colonies appearing on MSM were picked and purified by repeated culturing on Potato Dextrose Agar (PDA) and were further identified by National Center of Fungal Taxonomy (NCFT), New Delhi. Out of the isolated fungi, in the present study Fusarium chlamydosporium SPFS2-g was used for the treatment of tannery wastewater (Fig. 1).

\section{Determination of minimum inhibitory concentration (MIC) for fungal strain}

The Cr-resistance of fungal isolate was evaluated on modified Lee's minimal medium (with $0.25 \%$ glucose) supplemented with 100,200 , $300,400,500,600$, and 700 ppm concentrations of hexavalent chromium. The petriplates were inoculated with $8 \mathrm{~mm}$ agar plugs from young fungal colonies, pre-grown on PDA and incubated at $28^{\circ} \mathrm{C}$ for seven days ${ }^{21}$. The fungal growth was used as a measure of viability and it was determined by measuring the change in mycelia length with the help of measuring scale at 24 hours interval from the $3^{\text {rd }}$ day to the $7^{\text {th }}$ day post-inoculation ${ }^{22}$. The minimum inhibitory concentration for $\mathrm{Cr}(\mathrm{VI})$ [MIC $\mathrm{Cr}(\mathrm{VI})]$ was defined as the concentration of hexavalent chromium that inhibits visible growth of the fungal isolate.

\section{Fungal inoculum preparation}

For tannery wastewater bioremediation studies, the fungal inoculum was prepared in the form of mycelial pellets. Erlenmeyer flasks (250 $\mathrm{ml}$ capacity) containing $100 \mathrm{ml}$ potato dextrose broth (PDB) and streptopenicillin (100 ppm) were inoculated with mycelial discs ${ }^{19}$. These flasks were incubated at $30{ }^{\circ} \mathrm{C}$ for 5 days in orbital shaker at $150 \mathrm{rpm}$. The mycelium thus obtained was filtered by cheesecloth and air-dried on sterilized petriplates. Fungal pellets were prepared by cutting in approximately $1.5-2.0 \mathrm{~mm}$ size. The fungal pellets $(2 \% \mathrm{w} / \mathrm{v})$ were inoculated in combined tannery effluent amended with $0.1 \%$ glucose and $0.1 \%$ 
ammonium nitrate. The $\mathrm{pH}$ was maintained at 5.30 and the flasks were incubated at $30{ }^{\circ} \mathrm{C}$ in a shaker for six days at $150 \mathrm{rpm}$. The wastewater samples were collected at different time intervals $(2 \mathrm{~d}, 4 \mathrm{~d}$ and $6 \mathrm{~d})$ and reduction in $\mathrm{COD}$, color, $\mathrm{Cr}(\mathrm{VI})$ and other pollution parameters were measured.

\section{Physico-chemical analysis of the tannery wastewater}

The tannery wastewater samples were analyzed for physico-chemical parameters as per standard methods for wastewater analysis. Chemical oxygen demand (COD) and total suspended solids (TSS) were determined according to American Public Health Association (APHA) methods ${ }^{23}$. Color was measured spectrophotometrically (465 $\mathrm{nm})$ according to the method of Bajpai et al. ${ }^{24}$. The hexavalent chromium [ $\mathrm{Cr}(\mathrm{VI})]$ was determined colorimetrically using the diphenylcarbazide (DPC) method $^{23}$.

Other parameters of the wastewater e.g. $\mathrm{pH}$, electrical conductivity (EC), and total dissolved solids (TDS) were measured using Multi Parameter Water Analyzer Kit (WTW, Germany). Sodium, chloride and nitrate ions were measured by Thermo Scientific Orion DUAL STAR ion meter while turbidity was measured by Digital Turbidity Meter (Environmental and Scientific Instruments Co., India).

The data obtained in the study were analyzed by Duncan's Multiple Range Test using SPSS Inc. (v 17.0) software. The differences between means were considered significant at values of pd"0.05.

\section{RESULTS AND DISCUSSION}

\section{Isolation and Screening of fungi}

The fungal strain Fusarium chlamydosporium SPFS2-g was isolated from tannery effluent enriched soil by serial dilution technique. The isolate exhibited MIC for $\mathrm{Cr}(\mathrm{VI})$ as $500 \mathrm{ppm}$. The results indicated that some native fungi have a marked adaptation to heavy metals under constant metal stress for a long time, and the toxic metals were even used as micronutrients by these growth stimulated fungi ${ }^{25}$. Similar to our findings, Aspergillus niger, Aspergillus lentulus, Penicillium sp., and Fusarium solani isolated from contaminated sites have been reported to tolerate $1000 \mathrm{ppm} \mathrm{Cr}(\mathrm{VI})^{17,26,27}$. The tolerance to $\mathrm{Cr}(\mathrm{VI})$ occur by various mechanisms such as transport across the cell membrane, biosorption to cell walls and entrapment in extracellular capsules, precipitation, complexation and oxidation-reduction reactions ${ }^{15}$.

\section{Physico-chemical characteristics of the tannery wastewater before and after treatment with Fusarium chlamydosporium}

The combined tannery effluent used in bioremediation studies was dark grayish in color with unpleasant smell. The high values of $\mathrm{pH}, \mathrm{EC}, \mathrm{COD}$, color, TSS and total dissolved solids (TDS) were recorded in the effluent (Table 1). The high electrical conductivity and TDS were due to the presence of inorganic substances and salts whereas elevated amount of COD was ascribed to high amount of organic compounds which were not affected by the bacterial decomposition ${ }^{28}$. Besides, significant concentration of sodium, potassium, calcium, chloride and nitrate ions were also observed. Various

Table 1: Physico-chemical characteristics of untreated tannery wastewater

\begin{tabular}{lc}
\hline Parameters & Values $^{*}$ \\
\hline $\mathrm{pH}$ & $9.16 \pm 0.20$ \\
$\mathrm{TDS}\left(\mathrm{mg} \mathrm{L}^{-1}\right)$ & $17650 \pm 20.10$ \\
$\mathrm{TSS}\left(\mathrm{mg} \mathrm{L}^{-1}\right)$ & $1694 \pm 11.20$ \\
Turbidity (NTU) & $505 \pm 2.00$ \\
$\mathrm{COD}\left(\mathrm{mg} \mathrm{L}^{-1}\right)$ & $5776 \pm 30.10$ \\
$\mathrm{Color}\left(\mathrm{CU}^{2}\right)$ & $1984.85 \pm 12.80$ \\
$\mathrm{EC}\left(\mathrm{mS} \mathrm{cm}^{-1}\right)$ & $35.3 \pm 0.25$ \\
$\mathrm{Na}\left(\mathrm{mg} \mathrm{L}^{-1}\right)$ & $3080 \pm 35.60$ \\
$\mathrm{Cl}\left(\mathrm{mg} \mathrm{L}^{-1}\right)$ & $4700 \pm 40.10$ \\
$\mathrm{NO}{ }_{3}^{-}\left(\mathrm{mg} \mathrm{L}^{-1}\right)$ & $600 \pm 5.00$ \\
$\mathrm{Ca}{ }^{2+}\left(\mathrm{mg} \mathrm{L}^{-1}\right)$ & $258 \pm 12.00$ \\
$\mathrm{~K}^{+}\left(\mathrm{mg} \mathrm{L}^{-1}\right)$ & $290 \pm 11.50$ \\
$\mathrm{Cr}(\mathrm{VI})\left(\mathrm{mg} \mathrm{L}^{-1}\right)$ & $9.86 \pm 0.180$ \\
$\mathrm{Total} \mathrm{Cr}\left(\mathrm{mg} \mathrm{L}^{-1}\right)$ & $12.260 \pm 0.556$ \\
$\mathrm{~Pb}(\mathrm{II})\left(\mathrm{mg} \mathrm{L}^{-1}\right)$ & $0.965 \pm 0.0140$ \\
$\left.\mathrm{Total} \mathrm{Pb} \mathrm{(mg} \mathrm{L}{ }^{-1}\right)$ & $1.126 \pm 0.0131$ \\
$\mathrm{Cu}\left(\mathrm{mg} \mathrm{L}^{-1}\right)$ & $0.258 \pm 0.0013$ \\
$\mathrm{Zn}\left(\mathrm{mg} \mathrm{L}^{-1}\right)$ & $0.529 \pm 0.0028$ \\
$\mathrm{Mn}\left(\mathrm{mg} \mathrm{L}^{-1}\right)$ & $0.392 \pm 0.0090$ \\
\hline
\end{tabular}

${ }^{*}=$ Mean \pm SD of three replicates 


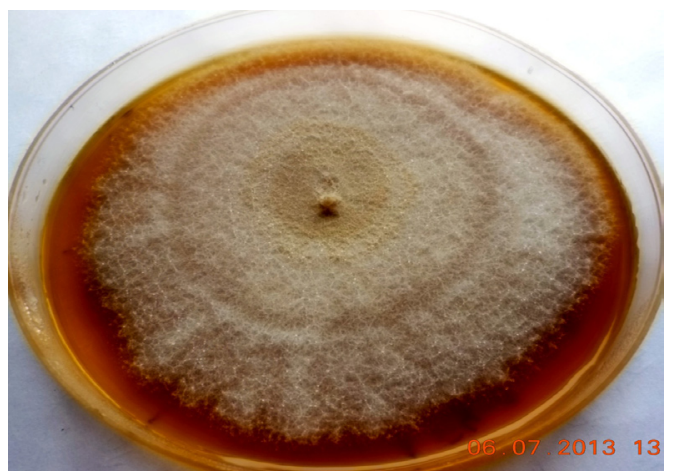

Fig. 1: Fusarium chlamydosporium SPFS2-g colony

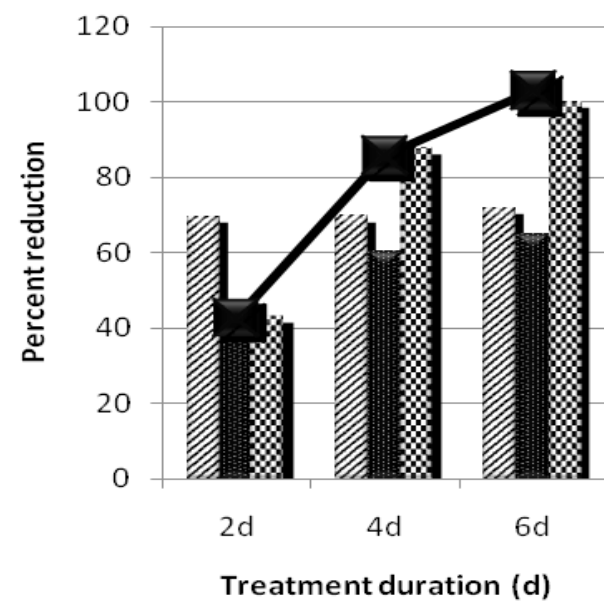

heavy metals present in the combined tannery effluent were $\mathrm{Cr}(\mathrm{VI})$, Total $\mathrm{Cr}, \mathrm{Pb}(\mathrm{II})$, Total $\mathrm{Pb}, \mathrm{Cu}, \mathrm{Zn}$ and $\mathrm{Mn}$. The tannery effluent characteristics were found to be in agreement with the previous studies ${ }^{29}$, 30.

Many microorganisms could develop potential to biodegrade the recalcitrant pollutants when they are exposed to polluted environment ${ }^{31}$ extended time duration. On this line, the treatment of tannery wastewater with Fusarium chlamydosporium SPFS2-g isolated from tannery wastewater affected soil resulted in significant reduction of pollution parameters after six days, concomitant with the increase in fungal dry weight (Table 2; Fig. 2). The

0.07

0.068

0.066

0.064

0.062

0.06

0.058

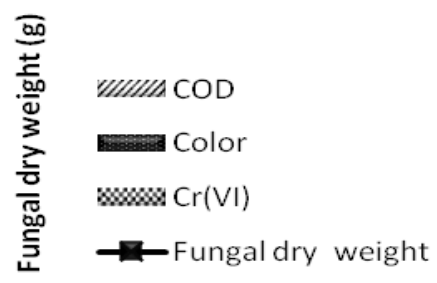

0.056

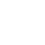

Table. 2: Physico-chemical characteristics* of tannery wastewater after different treatment durations (2d, 4d, and 6d) with Fusarium chlamydosporium SPFS2-g (Figures in parenthesis show \% reduction)

\begin{tabular}{lccc}
\hline Parameters & $\mathbf{2 d}$ & Treatment duration & \\
& & $\mathbf{4 d}$ & $\mathbf{6 d}$ \\
\hline $\mathrm{pH}$ & $4.80^{\mathrm{a}} \pm 0.11$ & $4.65^{\mathrm{b}} \pm 0.20$ & $4.60^{\mathrm{b}} \pm 0.12$ \\
$\mathrm{COD}\left(\mathrm{mg} \mathrm{L}^{-1}\right)$ & $1761.00^{\mathrm{a}} \pm 15.71(69.51)$ & $1759.66^{\mathrm{a}} \pm 20.79(69.53)$ & $1628.66^{\mathrm{b}} \pm 14.29(71.80)$ \\
Color $(\mathrm{CU})$ & $1129.34^{\mathrm{a}} \pm 24.00(43.10)$ & $793.44^{\mathrm{b}} \pm 19.97(60.02)$ & $700.75^{\mathrm{c}} \pm 35.80(64.69)$ \\
$\mathrm{Cr}(\mathrm{VI})\left(\mathrm{mg} \mathrm{L}^{-1}\right)$ & $5.620^{\mathrm{a}} \pm 0.241(43.00)$ & $1.220^{\mathrm{b}} \pm 0.210(87.63)$ & $0.00^{\mathrm{c}}(100)$ \\
$\mathrm{TSS}\left(\mathrm{mg} \mathrm{L}^{-1}\right)$ & $1121.31^{\mathrm{a}} \pm 22.32(33.81)$ & $1098^{\mathrm{ab}} \pm 12.65(35.17)$ & $1076.12^{\mathrm{b}} \pm 18.46(36.47)$ \\
Turbidity (NTU) & $480^{\mathrm{a}} \pm 18(4.95)$ & $430^{\mathrm{b}} \pm 25(14.85)$ & $390^{\mathrm{b}} \pm 16(22.77)$ \\
$\mathrm{Na}^{+}\left(\mathrm{mg} \mathrm{L}^{-1}\right)$ & $3010^{\mathrm{a}} \pm 11.54(2.27)$ & $2860^{\mathrm{b}} \pm 18.00(7.14)$ & $2720^{\mathrm{c}} \pm 22.00(11.69)$ \\
$\mathrm{Cl}^{-}\left(\mathrm{mg} \mathrm{L}^{-1}\right)$ & $3690^{\mathrm{a}} \pm 22.56(21.49)$ & $3420^{\mathrm{b}} \pm 12.68(27.23)$ & $3390^{\mathrm{b}} \pm 12.78(27.87)$ \\
$\mathrm{NO}_{3}^{-}\left(\mathrm{mg} \mathrm{L}^{-1}\right)$ & $314^{\mathrm{a}} \pm 3.10(47.67)$ & $269^{\mathrm{b}} \pm 3.18(55.17)$ & $226^{\mathrm{c}} \pm 3.70(62.33)$ \\
& & &
\end{tabular}

$\bar{*}=$ Mean \pm SD $(n=3)$ Within each row, values not followed by same superscript are significantly different at pd"0.05 
final reduction in COD, color, $\mathrm{Cr}(\mathrm{VI})$, TSS, turbidity, $\mathrm{Na}^{+}, \mathrm{Cl}$, and $\mathrm{NO}_{3}^{-}$was $71.80,64.69,100,36.47$, $22.77,11.69,27.87$ and $62.33 \%$, respectively after fungal treatment of tannery wastewater. The steep decline in COD within first two days (69.51\%) was attributed to utilization of organics by the fungus during initial growth phase. Similarly, rapid decolorization of tannery wastewater was possibly achieved by oxidative degradation of the dye molecules ${ }^{32}$. The tannery wastewater also registered reduction in $\mathrm{pH}$ from 5.30 to 4.60 , due to release of organic acids by the fungal isolate. The acidic environment facilitated the bisorption of $\mathrm{Cr}(\mathrm{VI})$ ions. Many researchers have also reported highly acidic $\mathrm{pH}$ for $\mathrm{Cr}(\mathrm{VI})$ biosorption ${ }^{33,34}$. In aqueous solution, chromium ions generally exist in two stable oxidation states, trivalent and hexavalent. The former exists as $\mathrm{Cr}^{3+}, \mathrm{Cr}(\mathrm{OH})^{2+}$ and $\mathrm{Cr}(\mathrm{OH})_{2}{ }^{+}$in the $\mathrm{pH}$ range 1.0-6.0 and starts precipitating as $\mathrm{Cr}(\mathrm{OH})_{3}$ at a pH value > 6.0, while $\mathrm{Cr}^{6+}$ forms $\mathrm{H}_{2} \mathrm{CrO}_{4}$ and $\mathrm{HCrO}_{4}{ }^{\prime}$ species at $\mathrm{pH} 2.0-3.0^{35}$. Thus, at low $\mathrm{pH}$ values oxyanionic species of $\mathrm{Cr}^{6+}$ is likely to be attracted by the positively charged functional groups present on the fungal cell surface.

Similarly, the reduction in TSS and turbidity was ascribed to entrapment of suspended solid particles by the filamentous fungi ${ }^{36}$. Whereas, reduction in $\mathrm{NO}_{3}^{-}, \mathrm{Na}^{+}$and $\mathrm{Cl}$ ions might be attributed to utilization of these ions for growth by the fungal isolate $^{37}$.

\section{CONCLUSION}

Fusarium chlamydosporium SPFS2-g isolated from tannery effluent enriched soil exhibited detoxification of tannery wastewater. The treatment of tannery wastewater with Fusarium chlamydosporium resulted in the reduction of $\mathrm{COD}$, color, $\mathrm{Cr}(\mathrm{VI})$, total suspended solids (TSS), turbidity, $\mathrm{Na}^{+}, \mathrm{Cl}$, and $\mathrm{NO}_{3}{ }^{-}$in the order of $71.80,64.69,100,36.47$, $22.77,11.69,27.87$ and $62.33 \%$, respectively after six days of duration. As the bioremediation activity is highly regulated by cell metabolism, which in turn is controlled by media components such as carbon and nitrogen sources and their ratio in addition to other process parameters like $\mathrm{pH}$, incubation temperature and aeration. Thus, in a future there is a need to conduct process parameter optimization studies to improve the bioremediation efficiency of the isolate.

\section{ACKNOWLEDGEMENTS}

The first author (SS) acknowledges the Junior Research Fellowship (JRF) supported by UGC. The corresponding author (PM) gratefully acknowledges the financial support provided by Department of Biotechnology, Government of India in the form of research project.

\section{REFERENCES}

1. Eye, J.D., and Lawrence, L. Treatment of waste from a sole leather tannery. J. Water Pollut. Control Fed. 43: 2291-2303 (1971).

2. Rajalo, G., and Petrovskaya, T. Selective electrochemical oxidation of sulphides in tannery wastewater. Environ. Technol. 17: 605-612 (1996).

3. Sharma, S., and Malaviya, P. Bioremediation of tannery wastewater by Aspergillus niger SPFSL 2 - a isolated from tannery sludge. $J$. Basic Appl. Sci. 2: 88-93 (2013).

4. Goncalves, I.M.C., Gomes, A., Bras, R., Ferra, M.I.A., Amorin, M.T.P., and Porter, R.S. Biological treatment of effluent containing textile dyes. Coloration Technol. 116: 393-397 (2000).
5. Raj, E.M., Sankaran, D.P., Sreenath, S.K., Kumaran, S., and Mohan, N. Studies on treated effluent characteristics of a few tanneries at Crompet, Madras. Indian J. Environ. Prot. 16: 252-254 (1996).

6. Baig, M. A., Mir, M., Murtaza, S., and Bhatti, Z. I. Laboratory scale studies on removal of chromium from industrial wastes. J. Environ. Sci. 15: 417-422 (2003).

7. Gupta, V.K., Shrivastava, A.K., and Jain, N. Biosorption of chromium(VI) from aqueous solutions by green algae Spirogyra species. Water Res. 35: 4079-4085 (2001).

8. Malaviya, P., and Singh, A. Physicochemical technologies for remediation of chromiumcontaining waters and wastewaters. Crit. Rev. 
Env. Sci. Technol. 41: 1111-1172 (2011).

9. Chu, W. W. Dye removal from textile dye wastewaters using recycled alum sludge. Water Res. 35: 3147-3152 (2001).

10. Subbaiah, M.V., Kalyani, M.V.S, Reddy, G.S., Boddu, V.M., and Krishnaiah, A. Biosorption of $\mathrm{Cr}(\mathrm{VI})$ from aqueous solutions using Trametes Versicolor Polyporus fungi. E-J. Chem. 5(3): 499-510 (2008).

11. Volesky, B., and Holan, Z.R. Biosorption of heavy metals. Biotechnol. Progr. 11: 235-250 (1995).

12. Gavrilesca, M. Removal of heavy metals from the environment by biosorption. Eng. Life Sci. 4(3): 219-232 (2004).

13. Anand, P., Isar J., Saran, S., and Saxena, R.K. Bioaccumulation of copper by Trichoderma viride. Bioresour. Technol. 97: 1018-1025 (2006).

14. Gupta, R., Ahuja, P., Khan, S., Saxena, R.K., and Mohapatra, H. Microbial biosorbents: Meeting challenges of heavy metal pollution in aqueous solutions. Curr. Sci. 78(8): 967973 (2000).

15. Malik, A. Metal bioremediation through growing cells. Environ. Int. 30: 261-278 (2004).

16. Thacker, U., Parikh, R., Shouche, Y., and Madamwar, D. Hexavalent chromium reduction by Providencia sp. Process Biochem. 41: 1332-1337 (2006).

17. Srivastava, S., and Thakur, I.S. Evaluation of biosorption potency of Acinetobacter sp. for removal of hexavalent chromium from tannery effluent. Biodegradation. 18: 637-646 (2007).

18. Bai, R.S., and Abraham, T.E. Studies on enhancement of $\mathrm{Cr}$ (VI) biosorption by chemically modified biomass of Rhizopus nigricans. Water Res. 36: 1224-1236 (2002).

19. Srivastava, S., and Thakur, I.S. Isolation and process parameter optimization of Aspergillus sp. for removal of chromium from tannery effluent. Bioresour. Technol. 97: 1167-1173 (2006).

20. Cardenas-Gonzalez, J.F., and Rodrguez, I.A. Hexavalent Chromium removal by a Paecilomyces sp. fungal strain isolated from environment. Bioinorg. Chem. Appl., Article
I.D. 676243 , 1-6 (2010).

21. Ezzouhri, L., Castro, M., Moya, M., Espinola, F., and Lairini, K. Heavy metal tolerance of filamentous fungi isolated from polluted sites in Tangier, Morocco. Afr. J. Microbiol. Res. 3: 35-48 (2009).

22. Shugaba, A., Nok, A.J., Ameh, D.A., and Lori, J.A. Studies on growth of some filamentous fungi in culture solutions containing hexavalent chromium. Int. J. Biotechnol. Biochem. 6: 715722 (2010).

23. Greenberg, A.E. Connors, J.J. Jenkins, D. and Franson, M.A. Standard Methods for the Examination of Water and Wastewater, 15th ed. American Public Health Association, Washington, DC (1995).

24. Bajpai, P., Mehna, A., and Bajpai, P.K. Decolorization of Kraft bleach plant effluent with white-rot fungus Tramates versicolor. Process Biochem. 28: 377-384 (1993).

25. Zhang, Y., Liu, M., Shi, X., and Zhao Z. Dark septate endophyte (DSE) fungi isolated from metal polluted soils: their taxonomic position, tolerance, and accumulation of heavy metals in vitro. J. Microbiol. 46: 624-632 (2008).

26. Sen, M. A Comparative Study on Biosorption of $\mathrm{Cr}(\mathrm{VI})$ by Fusarium solani under different growth conditions. J. Appl. Sci. 2: 146-152 (2012).

27. Fukuda, T., Ishino, Y., Ogawa, A., Tsutsumi, K., and Morita, H. Cr(VI) reduction from contaminated soils by Aspergillus sp. N2 and Penicillium sp. N3 isolated from chromium deposits. J. Gen. Appl. Microbiol. 54:295-303 (2008).

28. Nagarajan, P., and Ramchandramoorthy, T.R. Oil and grease removal from steel industry wastewater by chemical treatment. J. Ecotoxicol. Environ. Monit. 12: 181-184 (2002).

29. Mishra, K., Gupta, K., and Rai, U.N. Bioconcentration and phytotoxicity of chromium in Eichhornia crassipes. J. Environ. Biol. 30: 521-526 (2009).

30. Lofrano, G., Meric, S., Zengin, G.E., and Orhon, D. Chemical and biological treatment technologies for leather tannery chemicals and wastewaters: a review. Sci. Total Environ. 461-462: 265-281 (2013).

31. Chandra, R., and Singh, R. Decolourisation 
and detoxification of rayon grade pulp paper mill effluent by mixed bacterial culture isolated from pulp paper mill effluent polluted site. Biochem. Eng. J. 61: 49-58 (2012).

32. Mohorcic, M.,Teodorovic, S., Golob, V., and Friedrich, J. Fungal and enzymatic decolorization of artificial textile dye baths. Chemosphere 63: 1709-1717 (2006).

33. Merrin, J.S., Sheela, R., Saswathi, N., Prakasham, R.S., and Ramakrishna, S.V. Biosorption of chromium VI using Rhizopus arrhizus. Ind. J. Exp. Biol. 36: 1052-1055 (1998).

34. Bai, R.S., and Abraham, T.E. Biosorption of $\mathrm{Cr}(\mathrm{VI})$ from aqueous solution by Rhizopus nigricans. Bioresour. Technol. 79: 73-81
(2001).

35. Rai, D., Sass, B.M., and Moore, D.A. Solubility of amorphous $\mathrm{Cr}$ (III), Fe (II) hydroxide solid solutions. Inorg. Chem. 26: 2228-2232 (1987).

36. Fakhrul-Razi, A., and Molla, A.H. Enhancement bioseparation and dewaterability of domestic wastewater sludge by fungal treated dewatered sludge. J. Hazard. Mater. 147: 350-356 (2007).

37. Mert, H.H., and Dizbay, M. The effect of osmotic pressure and salinity of the medium on the growth and sporulation of Aspergillus niger and Paecilomyces lilacinum species. Mycopathologia. 61: 125-127 (1977). 